\title{
SYNTHESIS OF NOVEL METHOXY SUBSTITUTED BENZOTHIAZOLE DERIVATIVES AND ANTIBACTERIAL ACTIVITY AGAINST ESCHERICHIA COLI
}

\author{
AKHILESH GUPTA* \\ Department of Pharmaceutical Chemistry, Kunwar Haribansh Singh College of Pharmacy, Jaunpur, Uttar Pradesh, India. \\ Email: 81.akgupta@gmail.com
}

Received: 26 June 2018, Revised and Accepted: 21 July 2018

\begin{abstract}
Objectives: Escherichia coli is a Gram-negative rod (bacillus) in the family Enterobacteriaceae. In general, it is harmless, but some special species could cause harmful infection. In the recent era, the number of antibiotics is available to combat infection caused by $E$. coli but because of resistance developed against available antibiotics research is continuously going on to synthesize newer antibiotic to overcome this problem. Synthesis and screening of benzothiazole derivatives have great importance in heterocyclic chemistry because of its potent and significant biological activities against E. coli especially methoxy substitution at benzothiazole.
\end{abstract}

Methods: Methoxy substituted benzothiazole derivatives were synthesized by reaction of 3- chloro-4-methoxy-aniline with potassium thiocyanate under temperature control and presence of bromine in glacial acetic acid and ammonia. Substituted nitrobenzamides then synthesized by condensation of 2-amino-4-chloro-5-methoxy-benzothiazole with 2 (3 or 4)-nitrobenzoyl chloride acid in the presence of dry pyridine and acetone. Finally, newly synthesized derivatives (K-01 to K-09) were synthesized through replacing of chlorine of nitrobenzamide by reaction with 2-nitroaniline, 3-nitroaniline, and 4-nitroaniline in the presence of dimethoxy formamide. Analytical characterization was performed by thin-layer chromatography, melting point, infrared, and nuclear magnetic resonance. Antibacterial activity was performed against $E$. coli by cup plate method (diffusion technique) using streptomycin as standard. Compound K-03 showed potent antibacterial activity against E. coli at both concentrations $50 \mu \mathrm{g} / \mathrm{mL}$ and $100 \mu \mathrm{g} / \mathrm{mL}$ as compared to standard.

Results: Compound D-03 exhibited excellent activity among all synthesized compounds.

Conclusion: In the present work, efforts have been made to synthesized methoxy substituted benzothiazole derivatives and screened for antibacterial activity. Compound K-03 found as most active against E. coli.

Keywords: Methoxy-benzothiazole, Benzothiazole, Antibacterial activity, 2-Substituted benzothiazole, Cyclization of benzothiazole, Escherichia coli.

(C) 2018 The Authors. Published by Innovare Academic Sciences Pvt Ltd. This is an open access article under the CC BY license (http://creativecommons. org/licenses/by/4. 0/) DOI: http://dx.doi.org/10.22159/ajpcr.2018.v11i9.28095

\section{INTRODUCTION}

Escherichia coli is a Gram-negative rod (bacillus) in the family Enterobacteriaceae. Most E. coli is normal commensals found in the intestinal tract. Pathogenic strains of this organism are distinguished from normal flora by their possession of virulence factors such as exotoxins [1-3]. Pathogenic E. coli can be classified into pathotypes by their virulence factors, together with the type of disease. The six pathotypes capable of producing gastrointestinal disease in humans are enteropathogenic E. coli, enterotoxigenic E. coli, enteroaggregative $E$. coli, enteroinvasive $E$. coli, diffusely adherent $E$. coli, and enterohemorrhagic E. coli [4-7]. Most strains of these bacteria are harmless but a specific strain of $E$. coli that causes illness. It was first recognized as a cause of illness during an outbreak of hemorrhagic colitis (severe bloody diarrhea) in 1982 since anyone can become infected with $E$. coli. The elderly and children under 5 years of age are at greatest risk of developing a serious illness [8]. In the recent era, the number of antibiotics is available to combat infection caused by $E$. coli, but because of resistance developed against available antibiotics research is continuously going on to synthesize newer antibiotic to overcome this problem. Benzothiazole is a therapeutically important privileged bicyclic ring system contains sulfur and nitrogen as a heteroatom. Synthesis and screening of benzothiazole derivatives have great importance in heterocyclic chemistry because of its potent and significant biological activities. Substitution at C-2 of benzothiazole nucleus has emerged in its usage as a core structure in the diversified therapeutically applications [9-13]. As per reported biological activities of benzothiazole derivatives, it was found that change of the structure of substituent group at benzothiazole nucleus commonly results in the change of its bioactivities. Commonly change of substitution at C-2 benzothiazole nucleus especially with aryl-nitro has already been proven its therapeutic importance. Till date, various biological activities for benzothiazole derivatives have been reported as antitumor, antitubercular, antimalarial, anticonvulsant, anthelmintic, analgesic, anti-inflammatory, antibacterial and antifungal, a topical carbonic anhydrase inhibitor, and an antihypoxic [14-17]. 2-substituted benzothiazole derivatives were first discovered in 1887 by A. W. Hofmann as simple cyclization mechanism and number of the synthetic scheme has been reported. The most common and classical method were reported as direct method that involved condensation of an orthoaminothiophenol with a substituted aromatic aldehyde, carboxylic acid, acyl chloride or nitrile to synthesize C-2 substituted benzothiazoles, but it was found that this method is not appropriate for majority of substituted C-2 aryl benzothiazoles because the main difficulty encountered in synthesis of the readily oxidisable 2-aminothiophenols bearing substituent groups. For the above-said reason, some other methods were reported and extensively used in the laboratories that based on the use of the potassium ferricyanide radical cyclization of thiobenzanilides [18]. This method was named as Jacobsen cyclization and popularized because it produced only one product. As per reported method, it involved cyclization onto either carbon atom ortho to the anilido nitrogen. Due to selective product synthesis, the Jacobsen cyclization was considered as a highly effective strategy for benzothiazole synthesis, for example, for the synthesis of substituted benzothiazoles, radical cyclization of the 3-fluoro- or 3,4-difluorosubstituted thiobenzanilides [19-28]. The present work concern with the synthesis of methoxy and aryl-nitro substituted benzothiazole 
derivatives followed by the antibacterial activity for a structure-activity relationship.

\section{METHODS}

Synthesis of substituted benzothiazole (Compound Code 1-KB) Synthesis of substituted benzothiazole nucleus was achieved by adding $8 \mathrm{~g}(0.08 \mathrm{~mol})$ of potassium thiocyanate, and $1.45 \mathrm{~g}(0.01 \mathrm{~mol})$ of 3-choloro-4-methoxy-aniline into $20 \mathrm{~mL}$ cooled glacial acetic acid in such a way that the temperature not exceeded above room temperature. Freezing mixture of ice and salt was used to control the temperature of reaction with continuous mechanical stirring. Again temperature control was maintained during the addition of a solution of $1.6 \mathrm{~mL}$ of bromine in $6 \mathrm{~mL}$ of glacial acetic acid using dropping funnel. The time of addition of bromine also considered to take around $105 \mathrm{~min}$ to control temperature. During the addition of bromine, the temperature was controlled to never rise beyond the room. As the addition of bromine was completed the solution stirred for $2 \mathrm{~h}$ but below room temperature. After that solution was again stirred at room temperature for $10 \mathrm{~h}$ and allowed to stand overnight to get precipitate followed by heating at $85^{\circ} \mathrm{C}$ on a steam bath after addition of $6 \mathrm{~mL}$ water and filtered hot (Filtrate-01). In the resulting precipitate, $10 \mathrm{~mL}$ of glacial acetic acid was added and heated with at $85^{\circ} \mathrm{C}$ and filtered hot (Filtrate-02). Finally, both filtrate combined and cooled at room temperature followed by neutralization with concentrated ammonia solution to $\mathrm{pH}-6$ to get precipitate. The resulting product treated with animal charcoal and recrystallized from benzene, ethanol of 1:1 to get substituted benzothiazole.

Synthesis of nitrobenzamide (Compound code 2-KB, 3-KB, and 4-KB) $5.36 \mathrm{~g}(0.026 \mathrm{~mol})$ of 2-(3 or 4)-nitrobenzoyl chloride was dissolved in dry acetone. Product 1-KB separately dissolved in dry pyridine and added dropwise into the solution of 2-(3 or 4)-nitrobenzoyl chloride with continuous stirring at room temperature. After complete addition stirring was continued for another $30 \mathrm{~min}$ then transferred into $200 \mathrm{~mL}$ ice cold water. Finally, recrystallized with ethanol to get intermediate nitrobenzamide compound 2-KB, 3-KB, and 4-KB.

\section{Synthesis of compound K-01 to K-09}

$0.008 \mathrm{~mol}$ of 2 ( 3 or 4 ) nitro-substituted aniline was refluxed with $2.7 \mathrm{~g}$ $(0.0075 \mathrm{~mol})$ of compound $2-\mathrm{KB}, 3-\mathrm{KB}$, and $4-\mathrm{KB}$ separately for $2 \mathrm{~h}$ in the presence of dimethoxy formamide (DMF). After $2 \mathrm{~h}$ reflux, the mixture cooled at room temperature and poured into crushed ice. The solid was separated, dried, and recrystallized with super dry alcohol to get novel benzothiazole derivatives K-01 to K-09 (Fig. 1).

\section{Analytical characterization}

Thin layer chromatography (TLC) was used to monitor reaction progress, completion and identification of newly synthesized compounds from starting material using solvent system butanol: ethyl acetate: benzene [1:2:1] and detection performed by exposing them to iodine vapors. The melting point of compounds was determined using the open capillaries method. Structure elucidation of compounds was done by IR and ${ }^{1}$ HNMR spectral study. SHIMADZU (8400S) used for IR spectral study ( $\mathrm{KBr}$ pellet technique). For the structure elucidation using $\mathrm{IR}$, frequency range for $\mathrm{Ar}-\mathrm{C}=\mathrm{C}, \mathrm{C}=\mathrm{O}, \mathrm{C}-\mathrm{S}$, and $\mathrm{C}-\mathrm{NO} 2$ was considered. Bruker AM $400{ }^{1} \mathrm{HNMR}$ instrument (at $400 \mathrm{MHz}$ ) was used using CDCL3 as a solvent and tetramethoxysilane as an internal standard. For structure elucidation by ${ }^{1} \mathrm{HNMR}$, NH proton that characterized benzothiazole was considered.

\section{Antibacterial activity against $\boldsymbol{E}$. coli}

The standard drug and synthesized compounds were dissolved in minimum quantity of DMF and adjusted and made up the volume with distilled water to get $50 \mu \mathrm{g} / \mathrm{mL}$ and $100 \mu \mathrm{g} / \mathrm{mL}$ concentrations. The antibacterial activity was performed by the cup plate method (diffusion technique). The fresh culture of bacteria was obtained by inoculating bacteria into peptone water liquid media and incubated at $37 \pm 2^{\circ} \mathrm{C}$ for $18-24 \mathrm{~h}$. This culture mixed with nutrient agar media $(20 \%)$ and poured into Petri dishes by following aseptic techniques. After solidification of the media, five bores were made at an equal distance using sterile steel cork borer ( $8 \mathrm{~mm}$ diameter). Into these cups, different concentrations of standard drug and synthesized compounds were introduced. DMF was used as a control. After the introduction of standard drug and synthesized compounds, the plates were placed in a refrigerator at $8.0-10^{\circ} \mathrm{C}$ for proper diffusion of drugs into the media. After $2 \mathrm{~h}$ of cold incubation, the Petri plates are transferred to the incubator and maintained at $37 \pm 2^{\circ} \mathrm{C}$ for $18-24 \mathrm{~h}$. After the incubation period, the Petri plates were observed for the zone of inhibition using a Vernier scale. The results evaluated by comparing the zone of inhibition shown by the synthesized compounds with the standard drug. The results are the mean value of the zone of inhibition measured in millimeter of two sets.

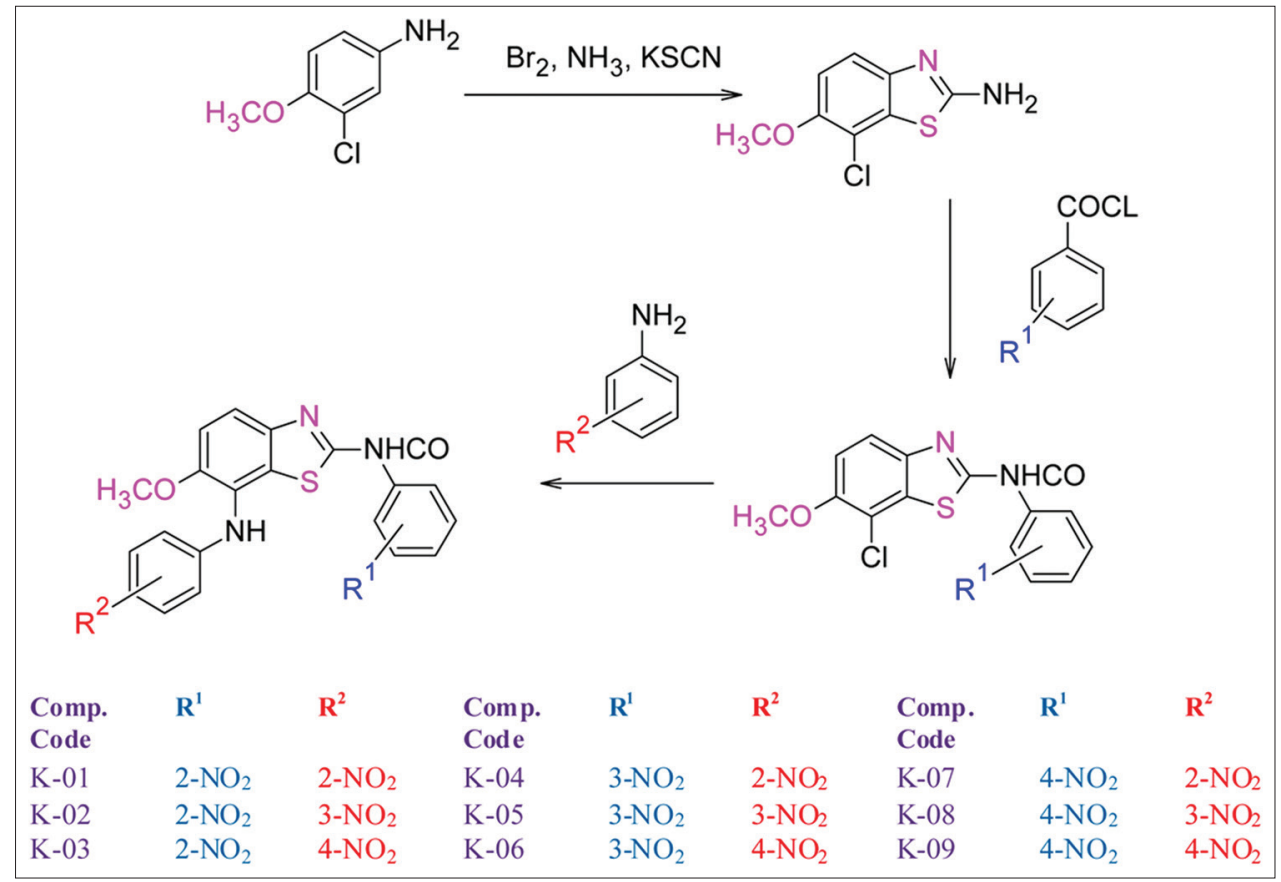

Fig. 1: Synthetic scheme 
Table 1: Analytical characterization of synthesized compounds

\begin{tabular}{|c|c|c|c|c|c|}
\hline $\begin{array}{l}\text { Comp. } \\
\text { Code }\end{array}$ & \%Yield & $\begin{array}{l}\text { Mel. } \\
\text { point }\left({ }^{\circ} \mathrm{C}\right)\end{array}$ & TLC (Rf) & IR spectral study & ${ }^{1} \mathrm{HNMR}$ spectral study (400 Hz, DMSO-d6) \\
\hline D-01 & 71 & 261 & 0.41 & $\begin{array}{l}1456 \mathrm{~cm}^{-1} \text { Ar C }=\mathrm{C}, 1632 \mathrm{~cm}^{-1} \mathrm{C}=0,1245 \mathrm{~cm}^{-1} \\
\mathrm{C}-\mathrm{S}, 1544 \mathrm{~cm}^{-1} \mathrm{C}-\mathrm{NO}_{2}\end{array}$ & $\begin{array}{l}\delta 4.61,(\mathrm{~s}, 1 \mathrm{H}, \mathrm{NH}), \delta 3.31\left(\mathrm{~s}, 3 \mathrm{H}, \mathrm{CH}_{3}\right), \delta \\
7.10-7.72(\mathrm{~m}, 10 \mathrm{H}, \mathrm{Ar}-\mathrm{H}), \delta 8.89(\mathrm{~s}, 1 \mathrm{H}, \mathrm{CONH})\end{array}$ \\
\hline D-02 & 72 & 260 & 0.43 & $\begin{array}{l}1454 \mathrm{~cm}^{-1} \mathrm{Ar} \mathrm{C}=\mathrm{C}, 1640 \mathrm{~cm}^{-1} \mathrm{C}=0,1257 \mathrm{~cm}^{-1} \\
\mathrm{C}-\mathrm{S}, 1575 \mathrm{~cm}^{-1} \mathrm{C}-\mathrm{NO}_{2}\end{array}$ & $\begin{array}{l}\delta 4.52,(\mathrm{~s}, 1 \mathrm{H}, \mathrm{NH}), \delta 3.39\left(\mathrm{~s}, 3 \mathrm{H}, \mathrm{CH}_{3}\right), \delta \\
7.18-7.85(\mathrm{~m}, 10 \mathrm{H}, \mathrm{Ar}-\mathrm{H}), \delta 9.10(\mathrm{~s}, 1 \mathrm{H}, \mathrm{CONH})\end{array}$ \\
\hline D-03 & 68 & 266 & 0.46 & $\begin{array}{l}1454 \mathrm{~cm}^{-1} \mathrm{Ar} \mathrm{C}=\mathrm{C}, 1652 \mathrm{~cm}^{-1} \mathrm{C}=0,1241 \mathrm{~cm}^{-1} \\
\mathrm{C}-\mathrm{S}, 1523 \mathrm{~cm}^{-1} \mathrm{C}-\mathrm{NO}_{2}\end{array}$ & $\begin{array}{l}\delta 4.55,(\mathrm{~s}, 1 \mathrm{H}, \mathrm{NH}), \delta 3.30\left(\mathrm{~s}, 3 \mathrm{H}, \mathrm{CH}_{3}\right), \delta \\
7.19-7.62(\mathrm{~m}, 10 \mathrm{H}, \mathrm{Ar}-\mathrm{H}), \delta 8.80(\mathrm{~s}, 1 \mathrm{H}, \mathrm{CONH})\end{array}$ \\
\hline D-05 & 69 & 256 & 0.48 & $\begin{array}{l}1443 \mathrm{~cm}^{-1} \mathrm{Ar} \mathrm{C}=\mathrm{C}, 1626 \mathrm{~cm}^{-1} \mathrm{C}=0,1222 \mathrm{~cm}^{-1} \\
\mathrm{C}-\mathrm{S}, 1543 \mathrm{~cm}^{-1} \mathrm{C}-\mathrm{NO}_{2}\end{array}$ & $\begin{array}{l}\delta 4.56,(\mathrm{~s}, 1 \mathrm{H}, \mathrm{NH}), \delta 3.44\left(\mathrm{~s}, 3 \mathrm{H}, \mathrm{CH}_{3}\right), \delta \\
7.21-7.80(\mathrm{~m}, 10 \mathrm{H}, \mathrm{Ar}-\mathrm{H}), \delta 8.96(\mathrm{~s}, 1 \mathrm{H}, \mathrm{CONH})\end{array}$ \\
\hline D-06 & 79 & 271 & 0.42 & $\begin{array}{l}1421 \mathrm{~cm}^{-1} \mathrm{Ar} \mathrm{C}=\mathrm{C}, 1615 \mathrm{~cm}^{-1} \mathrm{C}=0,1212 \mathrm{~cm}^{-1} \\
\mathrm{C}-\mathrm{S}, 1554 \mathrm{~cm}^{-1} \mathrm{C}-\mathrm{NO}_{2}\end{array}$ & $\begin{array}{l}\delta 4.65,(\mathrm{~s}, 1 \mathrm{H}, \mathrm{NH}), \delta 3.41\left(\mathrm{~s}, 3 \mathrm{H}, \mathrm{CH}_{3}\right), \delta \\
7.09-7.66(\mathrm{~m}, 10 \mathrm{H}, \mathrm{Ar}-\mathrm{H}), \delta 9.15(\mathrm{~s}, 1 \mathrm{H}, \mathrm{CONH})\end{array}$ \\
\hline $\mathrm{D}-7$ & 65 & 269 & 0.52 & $\begin{array}{l}1423 \mathrm{~cm}^{-1} \mathrm{Ar} \mathrm{C}=\mathrm{C}, 1626 \mathrm{~cm}^{-1} \mathrm{C}=0,1220 \mathrm{~cm}^{-1} \\
\mathrm{C}-\mathrm{S}, 1540 \mathrm{~cm}^{-1} \mathrm{C}-\mathrm{NO}_{2}\end{array}$ & $\begin{array}{l}\delta 4.60,(\mathrm{~s}, 1 \mathrm{H}, \mathrm{NH}), \delta 3.30\left(\mathrm{~s}, 3 \mathrm{H}, \mathrm{CH}_{3}\right), \delta \\
7.18-7.60(\mathrm{~m}, 10 \mathrm{H}, \mathrm{Ar}-\mathrm{H}), \delta 8.80(\mathrm{~s}, 1 \mathrm{H}, \mathrm{CONH})\end{array}$ \\
\hline D-08 & 67 & 264 & 0.40 & $\begin{array}{l}1421 \mathrm{~cm}^{-1} \mathrm{Ar} \mathrm{C}=\mathrm{C}, 1615 \mathrm{~cm}^{-1} \mathrm{C}=0,1212 \mathrm{~cm}^{-1} \\
\mathrm{C}-\mathrm{S}, 1554 \mathrm{~cm}^{-1} \mathrm{C}-\mathrm{NO}\end{array}$ & $\begin{array}{l}\delta 4.65,(\mathrm{~s}, 1 \mathrm{H}, \mathrm{NH}), \delta 3.40\left(\mathrm{~s}, 3 \mathrm{H}, \mathrm{CH}_{3}\right), \delta \\
7.10-7.68(\mathrm{~m}, 10 \mathrm{H}, \mathrm{Ar}-\mathrm{H}), \delta 8.83(\mathrm{~s}, 1 \mathrm{H}, \mathrm{CONH})\end{array}$ \\
\hline D-09 & 60 & 269 & 0.56 & $\begin{array}{l}1458 \mathrm{~cm}^{-1} \mathrm{Ar} C=\mathrm{C}, 1664 \mathrm{~cm}^{-1} \mathrm{C}=\mathrm{O}, 1244 \mathrm{~cm}^{-1} \\
\mathrm{C}-\mathrm{S}, 1552 \mathrm{~cm}^{-1} \mathrm{C}-\mathrm{NO}_{2}\end{array}$ & $\begin{array}{l}\delta 4.66,(\mathrm{~s}, 1 \mathrm{H}, \mathrm{NH}), \delta 3.44\left(\mathrm{~s}, 3 \mathrm{H}, \mathrm{CH}_{3}\right), \delta 7.20- \\
7.60(\mathrm{~m}, 10 \mathrm{H}, \mathrm{Ar}-\mathrm{H}), \delta 8.85(\mathrm{~s}, 1 \mathrm{H}, \mathrm{CONH})\end{array}$ \\
\hline
\end{tabular}

\section{RESULTS AND DISCUSSION}

Benzothiazole contains sulfur and nitrogen as heteroatom but imparts biological activity while substitution at the $\mathrm{C}-2$ position. In the present work, methoxy substituted benzothiazole nucleus while 2-(3 or 4)aryl nitro considered as rotating substitution at C-2 and C-4 position of benzothiazole nucleus derivatives were synthesized. The novel derivatives (K-01 to K-09) evaluated for antibacterial activity against E. coli. In the present work, nitro group considers as rotating basis on ortho, meta, and para position. The reason behind considering the nitro group as a substituent is the fungi rarely acquire resistance. TLC, melting point, IR, and $1 \mathrm{HNMR}$ were used for analytical characterization. In the TLC, the distance traveled by compound K-01 to K-09 was found to be different from that of the starting compound that proved synthesized compounds were different from parent one, even during TLC performance every time single spot was obtained; hence, it also reveals that synthesized compounds were free from impurity as well as reaction was completed. Structure elucidation by IR spectroscopy frequency range for $\mathrm{Ar} \mathrm{C}=\mathrm{C}, \mathrm{C}=\mathrm{O}, \mathrm{C}-\mathrm{S}$, and $\mathrm{C}-\mathrm{NO}_{2}$ was considered. In case of structure elucidation of by 1HNMR sharp characteristic signal at 7.0-8.0 ppm is observed and consider as benzothiazole in all the synthesized compounds (Table 1). Antibacterial activity performed at two concentration $50 \mu \mathrm{g} / \mathrm{mL}$ and $100 \mu \mathrm{g} / \mathrm{mL}$ using streptomycin as a standard drug against E. coli. Compound K-03 showed potent antibacterial activity against $E$. coli at both concentrations $50 \mu \mathrm{g} / \mathrm{mL}$ and $100 \mu \mathrm{g} / \mathrm{mL}$ as compared to standard (Table 2 and Fig. 2). The structure-activity relationship of newly synthesized compound revealed that 2-aryl nitro at C-2 and 4-aryl nitro at the C-4 position of methoxy-substituted benzothiazole derivative (Compound K-03) exhibited prominent inhibitory activity against $E$. coli.

\section{CONCLUSION}

In the present work, methoxy substituted novel benzothiazole derivatives were synthesized and screened for antibacterial activity against $E$. coli. The paucity of data showed that compound K-03 showed potent activity and could be considered for further clinical trials as antibacterial agents.

\section{CONFLICTS OF INTEREST}

The author has no conflicts of interest.

\section{AUTHOR'S CONTRIBUTION}

AS a single author, I carried out the complete experiment, data interpretation as well as manuscript writing for publication. No other coauthor contributed in this work.
Table 2: Result of antibacterial activity

\begin{tabular}{lll}
\hline Compound code & E. coli & \\
\cline { 2 - 3 } & $\mathbf{5 0} \boldsymbol{\mu g} / \mathbf{m L}$ & $\mathbf{1 0 0} \boldsymbol{\mu g} / \mathbf{m L}$ \\
\hline Streptomycin & 20 & 26 \\
K-1 & 07 & 12 \\
K-2 & 07 & 14 \\
K-3 & 20 & 24 \\
K-4 & 10 & 15 \\
K-5 & 12 & 14 \\
K-6 & 09 & 13 \\
K-7 & 10 & 16 \\
K-8 & 10 & 14 \\
K-9 & 08 & 13 \\
\hline
\end{tabular}

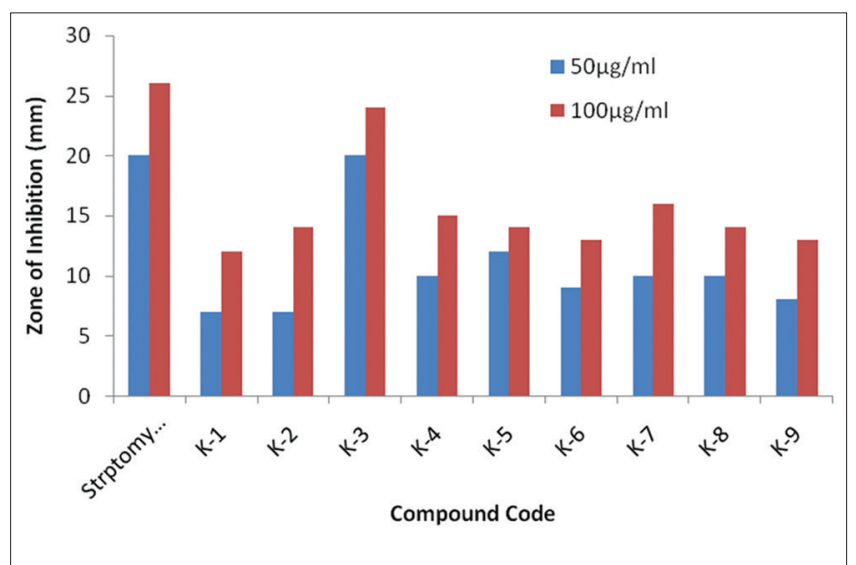

Fig. 2: Result of the zone of inhibition of synthesized compounds

\section{REFERENCES}

1. Bielaszewska M, Mellmann A, Zhang W, Köck R, Fruth A, Bauwens A, et al. Characterisation of the Escherichia coli strain associated with an outbreak of haemolytic uraemic syndrome in Germany, 2011: A microbiological study. Lancet Infect Dis 2011;11:671-6.

2. Aslantaş O, Erdoğan S, Cantekin Z, Gülaçti I, Evrendilek GA. Isolation and characterization of verocytotoxin-producing Escherichia coli $\mathrm{O} 157$ from Turkish cattle. Int J Food Microbiol 2006;106:338-42.

3. Avery LM, Williams AP, Killham K, Jones DL. Survival of Escherichia coli $\mathrm{O} 157: \mathrm{H} 7$ in waters from lakes, rivers, puddles and animal-drinking troughs. Sci Total Environ 2008;389:378-85. 
4. Berry ED, Wells JE. Soil solarization reduces Escherichia coli O157:H7 and total Escherichia coli on cattle feedlot pen surfaces. J Food Prot 2012;75:7-13.

5. Callaway TR, Edrington TS, Nisbet DJ. Isolation of Escherichia coli O157:H7 and salmonella from migratory brown-headed cowbirds (Molothrus ater), common grackles (Quiscalus quiscula), and cattle egrets (Bubulcus ibis). Foodborne Pathog Dis 2014;11:791-4.

6. Bryan A, Youngster I, McAdam AJ. Shiga toxin producing Escherichia coli. Clin Lab Med 2015;35:247-72.

7. Cobbaut K, Houf K, Douidah L, Van Hende J, De Zutter L. Alternative sampling to establish the Escherichia coli O157 status on beef cattle farms. Vet Microbiol 2008;132:205-10.

8. Foster G, Evans J, Knight HI, Smith AW, Gunn GJ, Allison LJ, et al. Analysis of feces samples collected from a wild-bird garden feeding station in Scotland for the presence of verocytotoxin-producing Escherichia coli O157. Appl Environ Microbiol 2006;72:2265-7.

9. Bradshaw TD, Wrigley S, Shi DF, Schultz RJ, Paull KD, Stevens MF, et al 2-(4-aminophenyl)benzothiazoles: Novel agents with selective profiles of in vitro anti-tumour activity. Br J Cancer 1998;77:745-52.

10. Alang G, Kaur R, Singh A, Budhlakoti P, Singh A, Sanwal R. Synthesis, characterization and antibacterial activity of certain (E)-1(1-(substitutedphenyl) ethylidene)-2-(6-methoxybenzo[d]thiazol-2-yl) hydrazine analogues. Int J Pharm Biol Arch 2010;1:56-61.

11. Suresh SH, Venkateshwara RJ, Jayaveera KN. Synthesis of 4-(2'-substituted benzothiaozles)-5-mercapto-3-(substituted)-1,2,4triazole derivatives for possible antimicrobiological activities. Res J Pharm Biol Chem Sci 2010;1:635-40

12. Basavaraja KM, Somashekhar B, Shivakumar B. Synthesis of 2-[(1-phenyl) (aryl) azo] methoxyeneimino-6-chloro/fluoro benzothiazoles and their antibacterial activity. Int J Pharm Tech Res 2010;2:1139-43

13. Vedavathi M, Sreenivasa GM, Jayachandran E. Synthesis, characterization and antimicrobial activity of fluoro benzothiaozle incorporated with 1,3,4-thiadiazole. J Pharm Sci Res 2010;2:53-63.

14. Pandurangan A, Sharma A, Sharma N, Sharma PK, Visht S. Synthesis and structural studies of novel benzothiazole derivative and evaluation of their antimicrobial activity. Der Pharm Chem 2010;2:316-24.

15. Rajeeva B, Srinivasulu N, Shatakumar SM. Synthesis and antimicrobial activity of some new 2-substituted benzothiazole derivatives. E-J Chem 2009;6:775-9

16. Malik J, Manvi FV, Nanjwade BK, Singh S. Synthesis and screening of some new 2-amino substituted benzothiazole derivatives for antibacterial activity. Drug Invent Today 2009;1:32-4

17. Patel NB, Shaikh FM. Synthesis of new pyridine based 4 -thiazolidinones incorporated benzothiazoles and evaluation of their antimicrobial activity. J Sci 2010;21:121-9

18. Barot HK, Mallika G, Sutariya BB, Shukla J, Nargund LV. Synthesis of nitrogen mustards of flouro-benzothiazoles of pharmacological interest. Res J Pharm Biol Chem Sci 2010;1:124-9.

19. Dua R, Sonwane SK, Srivastava SK, Srivastava SD. Greener and expeditious synthesis of 2-azetidinone derivative from 2-mercaptobenzothiazole and their pharmacological screening of the compounds using microwave irradiation. World J Chem 2010;5:52-6.

20. Bhusari KP, Amnerkar ND, Khedekar PB, Kale MK, Bhole RP. Synthesis and in vitro antimicrobial activity of some new 4-amino-N(1,3-Benzothiazol-2-yl) benzenesulphonamide derivatives. Asian J Res Chem 2008;1:53-8.

21. Sathe BS, Jayachandran E, Jagtap VA, Sreenivasa GM. Anthelmintic activity of newly synthesized moieties of fluoro benzothiazole Schiff's bases. Res J Pharm Biol Chem Sci 2011;2:510-5.

22. Sreenivasa GM, Jyachandran E, Shivakumar B, Jayaraj KK, Kumar V. Synthesis of bioactive molecule fluoro benzothiazole comprising potent heterocyclic moieties for anthelmintic activity. Arch Pharm Sci Res 2009;1:150-7.

23. Venkatesh P, Pandeya SN. Synthesis, characterization and antiinflammatory activity of some 2 -amino benzothiazole derivatives. Int J Chem Tech Res 2009;1:1354-8.

24. Shashank D, Vishawanth T, Prasha A, Balasubramaniam V, Nagendra A, Perumal P, et al. Synthesis of some substituted benzothiazole derivatives and its biological activities. Int J Chem Tech Res 2009;1:1224-31.

25. Kaur H, Kumar S, Singh I, Saxena KK, Kumar A. Synthesis, characterization and biological activity of various substituted benzothiazole derivatives. Dig J Nanomater Biostruct 2010;5:67-76.

26. Muttu CT, Bhanushali MD, Hipparagi SM, Tikare VP, Karigar A. Microwave assisted synthesis and evaluation of some fluoro, chloro 2-N(substituted Schiff's bases) aminobenzothiazoles derivatives for their anti-inflammatory activity. Int J Res Ayurv Pharm 2010;1:522-8.

27. Shafiq B, Zuhair ME, Elham A, Ibrahim SA. Synthesis and antimicrobial evaluation of 2-\{4-(T-Amino)-2-(But-2-yl-1-y10\}-1,3 benzoyhiazole derivatives. Int J Pharm Pharm Sci 2018;8:189-93.

28. Chauhan D, Siddiqui AA, Rajkumari K, Robin S. Synthesis, characterization and antimicrobial evaluation of some new benzothiazole derivatives. Int J Pharm Pharm Sci 2015;7:316-9. 